\title{
Application of dairy residue in peanut (Arachis hypogaea L.) cultivated in Northeastern Brazil
}

\author{
Abraão Cícero da Silva ${ }^{1 *}$, Jeandson Silva Viana ${ }^{2}$, José Fábio Ferreira de Oliveira ${ }^{2}$, José Jairo Florentino \\ Cordeiro Junior ${ }^{1}$, Edilma Pereira Gonçalves ${ }^{2}$, Vinicius Santos Gomes da Silva ${ }^{4}$, Adrielle Naiana Ribeiro \\ Soares $^{3}$
}

\author{
${ }^{1}$ Departamento de Agronomia, Universidade Federal Rural de Pernambuco. 52171-900, Recife, Pernambuco, Brazil \\ ${ }^{2}$ Unidade Acadêmica de Garanhuns, Universidade Federal Rural de Pernambuco. 55292-270, Garanhuns, \\ Pernambuco, Brazil \\ ${ }^{3}$ Universidade de Sergipe. 49060-108, Aracaju, Sergipe, Brazil \\ ${ }^{4}$ Centro de Ciências Agrárias, Universidade Federal de Alagoas, Rio Largo, Alagoas, Brazil
}

*Corresponding author: abraaocicero@yahoo.com.br, abraaocicero@yahoo.com.br

\begin{abstract}
Peanut (Arachis hypogaea L.) is one of the widely cultivated legume in tropical and subtropical regions. The aim of this study was to evaluate the agronomic characteristics of peanut (BR1) under different doses of dairy residue. The experiment was conducted as a randomized block design with three replicates. The treatments consisted of doses of milk residue: $0,2.5,5,7.5,10 \mathrm{~m}^{3} \mathrm{ha}^{-1}$ and an additional control containing phosphors and potassium (PK) at dose of 15 and $50 \mathrm{~kg} \mathrm{ha}^{-1}$. The following characteristics were determined in plants: leaf area, number of stems, shoot and root system length, dry weight of shoot and root system, number of pods and grain yield. The dose of $5 \mathrm{~m}^{3}$ ha ${ }^{-1}$ provided the highest agronomic characteristics. The grain yield was greater for the dose of $10 \mathrm{~m}^{3} \mathrm{ha}^{-1}$. The dairy residue can be used as a source of fertilizer on peanut crop by meeting their nutritional requirements.
\end{abstract}

Keywords: grain legume, organic fertilization, sewage sludge; sustainable agriculture.

Abbreviations: DRW_dry root weight; DWS_dry weight of shoot; GM_grain mass; LA_leaf area, PH_plant height; MP_mass of pod.

\section{Introduction}

Peanut (Arachis hypogaea L.) is one of the widely cultivated oil crop in tropical and subtropical regions of Asia, Africa, North America and South America, and also in 24.71 million hectares in the world with a production more than 41.2 million tonnes (Faostat, 2014). Several factors limit the production of peanuts, especially soil fertility conditions, being a very demanding culture for some nutrients, such as nitrogen, potassium, calcium, magnesium, phosphorus and sulfur. According to the study of Hippler et al. (2011) the calcium is very important element among the nutrients required by peanut, directly influencing the formation of grains.

To satisfy the nutritional needs of this crop a practice adopted in large scale is conventional chemical fertilization; however, this practice leads to more production costs. This is the main reason that researchers have raised interests in finding alternative and renewable sources of fertilization, which is a necessity especially for small farmers. Among the various research fields to find alternative sources of fertilization the study of industrial waste is area that has great importance. According to Lai et al. (2011) the growth of cities and industrial development generate large volumes of waste. These residues are not disposed at appropriate site and can be a threat to the environment and endanger human health. Dulewska and Oleszek (2002) showed that the sewage sludge is a residue rich in nitrogen, phosphorus, potassium and calcium. They show potential to supply partially and/or the whole nutritional need of the peanut plants during the whole productive cycle. According to research conducted by Saito (2007) sewage sludge has a potential to be used in fertilization by providing improvements in physical, chemical and biological conditions of soil, contributing to the increase in agricultural productivity. However, there is scarce research on dairy waste, which is type of secondary sewage sludge in industrialization process of dairy products. Recently, studies on this type of sludge have gained attention as an alternative and renewable source of fertilization. Melo et al. (2011) showed that residue derived from milk processing processes, dairy products and cleaning products of facilities presents considerable amounts of phosphorus and potassium, whose content can be variable depends on the processing of dairy products and may have potential for use in agriculture and plant nutrition. Gajendragadkar and Gogate (2016) conducted a comprehensive literature review on whey. They reported whey has the potential to be used in agriculture as a source of fertilizer. Silva et al. (2011) evaluated different concentrations of whey to provide the 
nitrogen concentrations of $0,50,100$ and $200 \mathrm{~kg} \mathrm{~N}$ per hectare in pasture and found satisfactory results. Therefore, the objective of this study was to evaluate the potential of dairy residue as fertilizer alternate source for the peanut crop.

\section{Results and Discussion}

\section{Growth characteristics of peanut}

The leaf area reached $48.49 \mathrm{~cm}^{2}$ when dairy residue dose of $4.41 \mathrm{~m}^{3} \mathrm{ha}^{-1}$ was used (Fig 2A). The dose corresponding to 10 $\mathrm{m}^{3} \mathrm{ha}^{-1}$ differed statistically, when compared with the control. Similar results were obtained by Melo et al. (2011), which evaluated the morphological responses of mombassa grass subjected to doses of liquid residue of dairy at concentrations of 200,400, 600 and $800 \mathrm{ml} \mathrm{pot}^{-1}$, by which they found quadratic relation. Vieira (2011) worked with different biofertilizers on peanut cultivation and did not find significant results for the initial growth. For the number of stems, the response was linear to the increasing dose of treatments, according to regression analysis (Fig 2B). However, there is not significant difference, when compared with the control (Table 1). Application of dairy residue has given the similar potential compared to chemical fertilizers for this variable. Similar result was verified by Santos et al. (2014) when evaluated the influence of liquid residue of agribusiness dairy on pasture, which also obtained linear response to the number of tillers with increasing doses. The leaf area is influenced by several factors, such as population density, climatic conditions, genetic factors, nutritional conditions among others. But in this case, the residue dose was the main determining factor, which showed a decrease from the maximum point, contributing to a reduction in leaf area. Oliveira et al. (2008) evaluated the implementation of leather industry residue as a source of nutrients and reported that the quadratic behavior for the application of residue is related to nutritional imbalance or toxic effects of residue. Cravo (1995) found that, in general, the industrial residues have some kind of heavy metal and the effect of these metals in the plants will vary depending on the dose and residue sources, which can decrease the formation of biomass.

The result corresponding to the height of the plants treated with the dairy waste showed quadratic behavior (Fig $3 \mathrm{~A}$ ), with maximum point of $12.35 \mathrm{~cm}$ to the dose of $3 \mathrm{~m}^{3}$ ha${ }^{1}$. The treatments corresponding to the doses of 0.5 and 10 $\mathrm{m}^{3} \mathrm{ha}^{-1}$ showed a significant effect on shoot height, compared with the control (Table 1). These results contradict those reported by Silva (2010), which reported the effect of different sources and timing of organic fertilizer on the development of peanut. They did not get significant effect on plant height upon applied doses. Morrill et al. (2012) studied the effect of the application of whey doses (0, $200,400,600,800$ and $1000 \mathrm{~m}^{3} \mathrm{ha}^{-1}$ ) on the height of the plants sorghum-sudan and forage millet. They observed a quadratic equation with highest value for the dose of $167 \mathrm{~m}^{3}$ $\mathrm{ha}^{-1}$. The length of the root system showed no significant difference (Table 1) and showed linear regression behavior for regression analysis after treatments with dairy waste (Fig $3 B)$. This growing response to the increasing residue doses was possibly caused due to the fact that dairy waste is a source of organic matter and contributes to the improvement of the physical quality and soil chemistry. Elayaraja and Singaravel (2009) stated that the increase in the root system growth is influenced by application of organic sources in the soil. This provides improvement in the physiochemical attributes of soil, increasing microbial activity, enabling a better development of root system. The dry weight of shoot showed no significant difference (Table 1) after treatments. For the dry mass of the root system, the doses of $0,2.5$ and $10 \mathrm{~m}^{3} \mathrm{ha}^{-1}$ differed from the witness, with higher average of $0.51,0.37$ and $0.35 \mathrm{~g}$ compared to control, respectively (Table 1 ). Regression analysis showed a linear response to the dry weight of shoot (Figure 4A). Figure $4 \mathrm{~B}$ shows that the dry mass of the root system has quadratic behavior with maximum point of $1.77 \mathrm{~g}$ for the dose of 6.26 $\mathrm{m}^{3} \mathrm{ha}^{-1}$. Similar results were found by Camilotti et al. (2012) which evaluated the dry biomass production and yield of peanuts grown in tropical soil amended with sewage sludge. They did not find significant differences for both mass of the shoot and the root system. Different results were obtained by Morrill et al. (2012), applying whey at doses of 0, 200, $400,600,800$ and $1000 \mathrm{~m}^{3} \mathrm{ha}^{-1}$. They obtained significant differences among the treatments, showing quadratic behavior with maximum point of dry biomass at a dose of $370 \mathrm{~m}^{3} \mathrm{ha}^{-1}$ in forage sorghum. Primo et al. (2010) observed that increase of organic waste doses increase the dry mass of the aerial part of the cotton plant.

\section{Peanut yield}

The number of peanut pods for treatments with dairy residue just showed statistical difference between the control (dose 0 ) and the additional control ( $P, K)$ (Table 1). The mass of pods and grain yield (Table 1 ) was higher at the dose of $10 \mathrm{~m}^{3} \mathrm{ha}^{-1}$. This is the best dose at which the alternative use of dairy residue fertilization provides a superior effect on peanut production in sandy soil conditions. This provides nutritional supply and probably improvements in physical-chemical soil conditions as a source of organic matter as well.

The regression analysis of data showed that the number of pods followed a quadratic equation with 7.4 pods (maximum) at dose of $7.5 \mathrm{~m}^{3} \mathrm{ha}^{-1}$ (Fig 5A), while the pod yield and grains showed linear behavior for the residues of doses applied (Figures 5B and $5 \mathrm{C}$ ). Other authors have also found satisfactory results for the production of other crops using doses of products derived from dairy residue such as serum. Queiroz (2013) applied $62.5 \mathrm{~m}^{3} \mathrm{ha}^{-1}$ of whey found in an field experiment and observed an increase of $938 \mathrm{~kg} \mathrm{ha}^{-1}$ in productivity of corn grains. Mantovani et al. (2015) evaluated the effect of whey serum as a source of nutrients for the corn and observed the increase in dry mass. Although significant differences observed for the mass of the pods and grains using some treatments, as previously described, but the values were lower than the genetic potential of the BR 1 peanut cultivar. According to Santos et al. (2009), the peanut cultivar BR 1 shows an average yield of $1800 \mathrm{~kg} \mathrm{ha}^{-1}$ of peanuts in shell. To achieve good productivity of peanut crop it is necessary to achieve high production of pod and grain filling. In this study the average number of pod was lower than the potential of cultivar. The treatment doses 
Table 1. Leaf area (LA) number of stems (NS), plant height (PH) length of the root system (LRS), dry weight of shoot (DWS), dry root weight (DRW) pods number (PN), mass of pod (MP) and grain mass (GM) of peanut seedlings fertilized with dairy waste doses and PK.

\begin{tabular}{|c|c|c|c|c|c|}
\hline Treatments & LA & NS & $\mathrm{PH}(\mathrm{cm})$ & LRS $(\mathrm{cm})$ & DWS (g) \\
\hline $0.0-\mathrm{PK}$ & $-4.20^{\mathrm{ns}}$ & $0.18^{\mathrm{ns}}$ & $-2.61 *$ & $-3.02^{\mathrm{ns}}$ & $-1.51^{\text {ns }}$ \\
\hline $2.5-\mathrm{PK}$ & $2.35^{\mathrm{ns}}$ & $0.22^{\mathrm{ns}}$ & $0.75^{\mathrm{ns}}$ & $-2.95^{\mathrm{ns}}$ & $-1.38^{\text {ns }}$ \\
\hline $5.0-\mathrm{PK}$ & $-4.20^{\mathrm{ns}}$ & $0.22^{\mathrm{ns}}$ & $-1.51 *$ & $0.11^{\mathrm{ns}}$ & $0.54^{\mathrm{ns}}$ \\
\hline $7.5-\mathrm{PK}$ & $2.35^{\text {ns }}$ & $0.23^{\mathrm{ns}}$ & $0.09^{\mathrm{ns}}$ & $-0.42^{\mathrm{ns}}$ & $-0.14^{\mathrm{ns}}$ \\
\hline $10.0-\mathrm{PK}$ & $-4.87 *$ & $0.21^{\mathrm{ns}}$ & $3.89 *$ & $-0.36^{\mathrm{ns}}$ & $1.35^{\mathrm{ns}}$ \\
\hline Treatments & DRW (g) & & NP & $\mathrm{MP}(\mathrm{kg})$ & GM (kg) \\
\hline $0.0-\mathrm{PK}$ & $-0.51 *$ & & $-2.53 *$ & $-188.10^{\text {ns }}$ & $-30.95^{\text {ns }}$ \\
\hline $2.5-\mathrm{PK}$ & $-0.37^{*}$ & & $0.06^{\mathrm{ns}}$ & $-138.10^{\mathrm{ns}}$ & $11.90^{\mathrm{ns}}$ \\
\hline $5.0-P K$ & $-0.13^{\mathrm{ns}}$ & & $0.00^{\mathrm{ns}}$ & $183.33^{\mathrm{ns}}$ & $-28.57^{\mathrm{ns}}$ \\
\hline $7.5-\mathrm{PK}$ & $0.07^{\mathrm{ns}}$ & & $0.03^{\mathrm{ns}}$ & $-123.81^{\mathrm{ns}}$ & $-61.90^{\mathrm{ns}}$ \\
\hline $10.0-\mathrm{PK}$ & $-0.35 *$ & & $0.33^{\mathrm{ns}}$ & $219.48 *$ & $76.19 *$ \\
\hline
\end{tabular}

* Significant to the additional control, the Dunnett test at $5 \%$ level of probability;

${ }^{\mathrm{N}}$ Not significant, the Dunnett test at $5 \%$ level of probability.

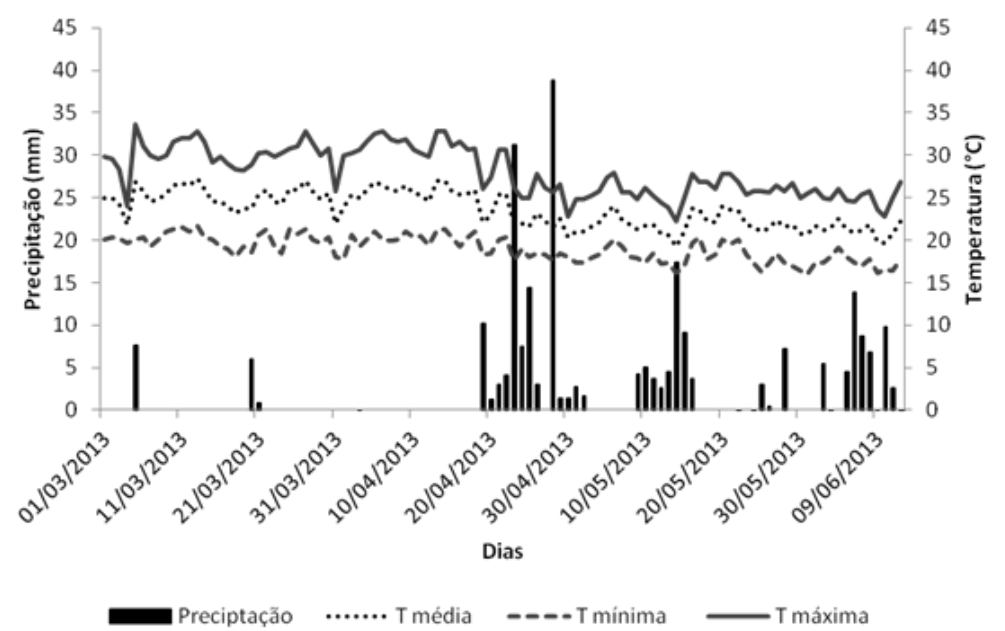

Fig 1. Data of precipitacion $(\mathrm{mm})$, maximum, minimum and average temperature $(\stackrel{\circ}{\mathrm{C}}$ ) during the period $3 / 1 / 2013$ to $6 / 15 / 2013$ in Garanhuns-PE city (Source: INMET, 2013).

A

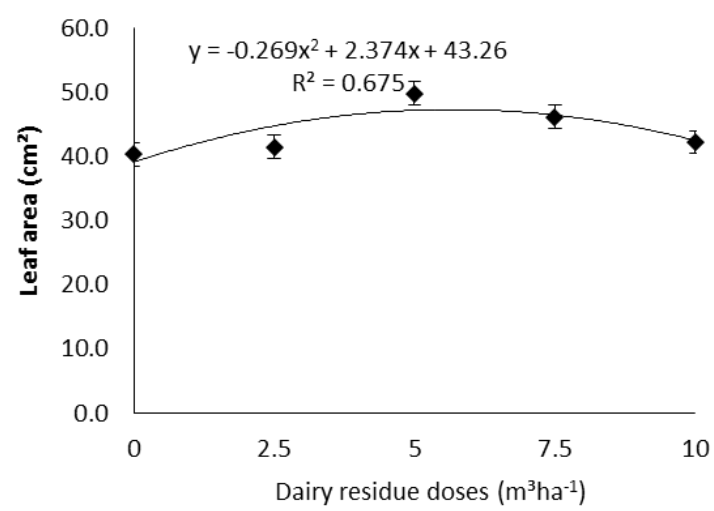

B

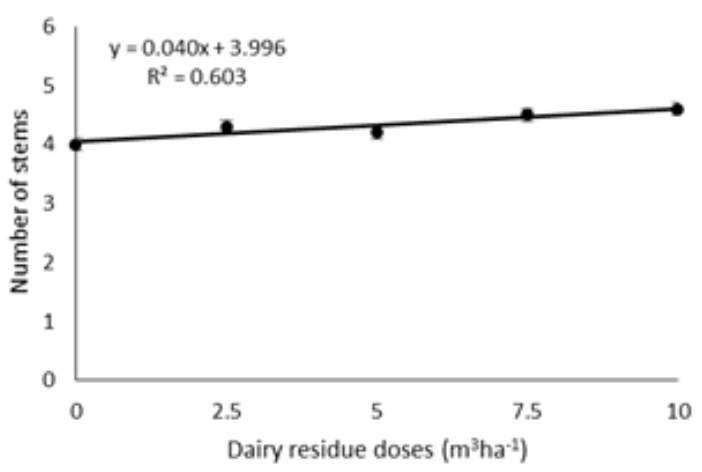

Fig 2. There should be a general legend. Leaf area (A) and number of stems (B) of peanut seedlings subjected to treatment with of dairy residue doses. 
A

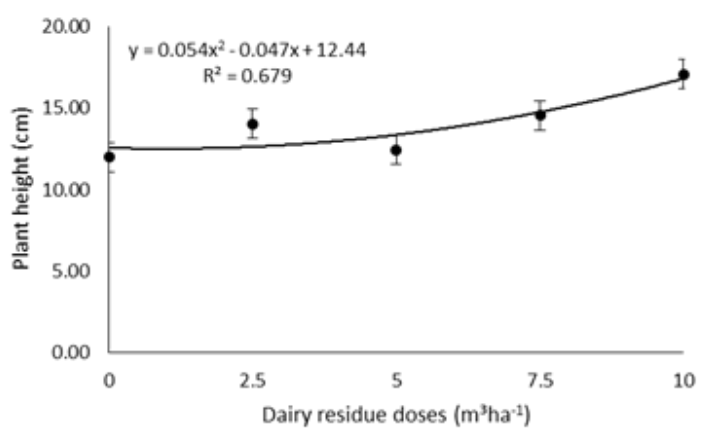

B

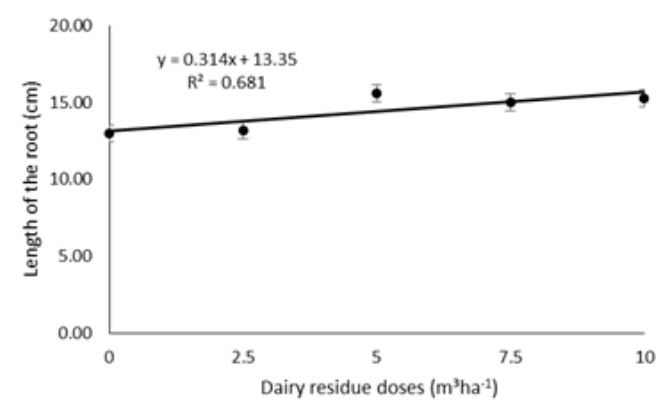

Fig 3. Plant height (A) and length of the root system (B) of peanut seedlings subjected to treatment with of dairy residue doses.
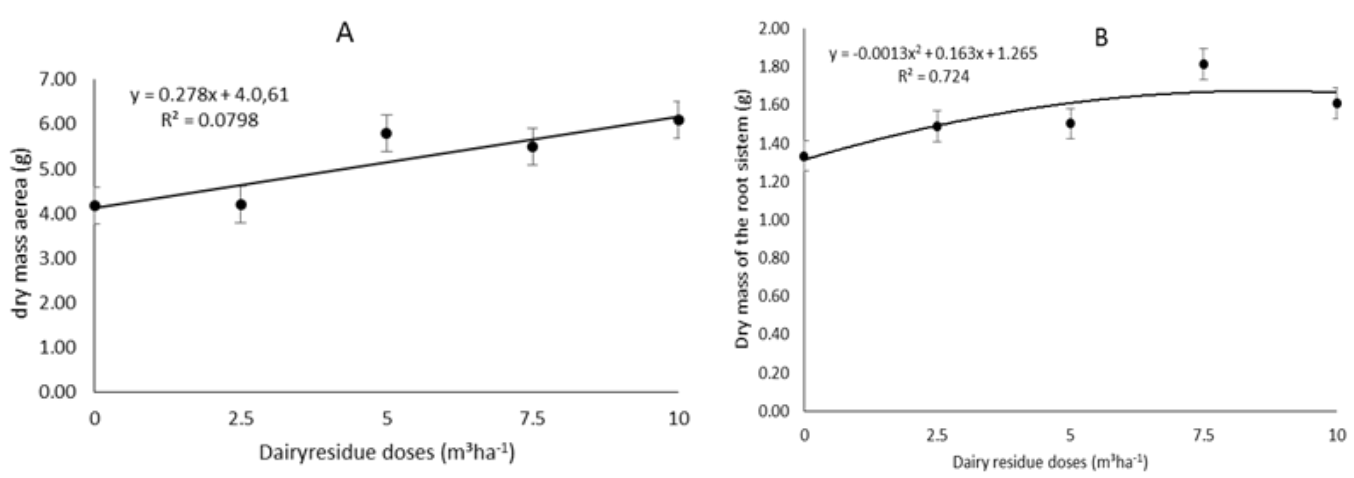

Fig 4. Dry mass area (A) and Dry mass of the root system (B) of peanut seedlings subjected to treatment with of dairy residue doses.
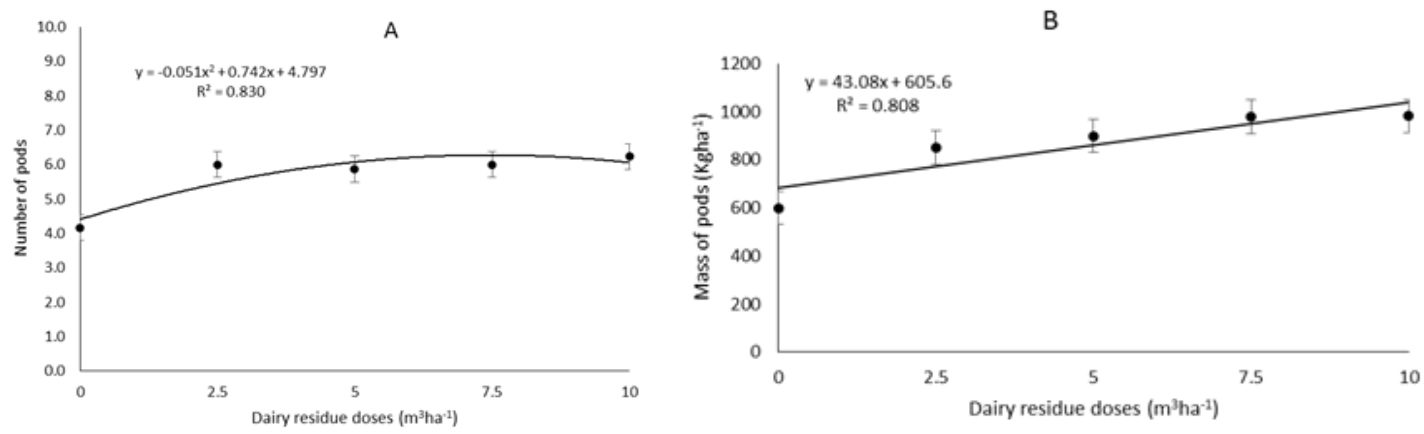

C

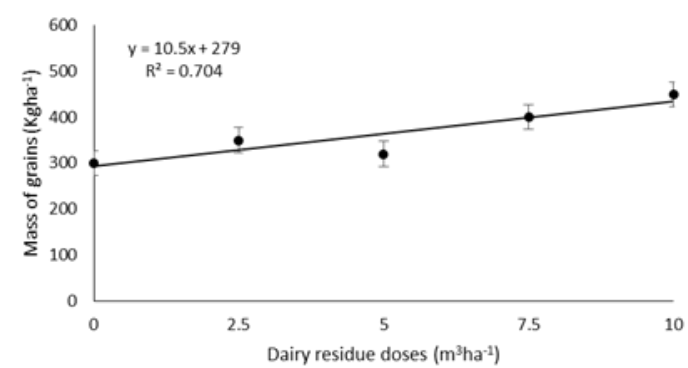

Fig 5. Number of pods (A), mass of pods (B) and mass of grains (C) of peanut seedlings subjected to treatment with of dairy residue doses. 
that we applied as whey residue did not work as chemical fertilizers, which rule out the possibility of low productivity because of available nutrients. This low number of pods can also be attributed to the high temperatures during flowering period of peanut (Figure 1) that ranged from 25 to $30^{\circ} \mathrm{C}$. According to Kvien (1995) peanut would produce fewer flowers in temperature ranges of 24 to $33^{\circ} \mathrm{C}$, which consequently causes a lower production of pods.

Another factor that contributes to the low productivity was the infestation of Cercosporiose, damaging the leaves; thus, reducing the efficiency of photosynthetic process and hurting productivity due to less assimilation of sap. Furthermore, Figure 1 shows that the rains occurred frequently starting the sowing month and the temperature exceeded $25^{\circ} \mathrm{C}$, which made the environment suitable for development of fungi, hindering and reducing the development of the grains. Godoy et al. (1999) reported that the low productivity in the peanut crop occurs in times of high precipitation, where it rains almost every day, which facilitates the emergence of diseases such as cercosporioses and verrugoses. Those conditions are also difficult to practice the spraying for the control of pests and diseases.

\section{Materials and methods}

\section{Description of the experimental site}

The experiment was conducted under field conditions in Pernambuco Brazil, in areas belonging to the Rural Federal University of Pernambuco-UFRPE, with the following coordinates: Latitude 853'25 "south, longitude 3629'34" $\mathrm{W}$, at an average altitude of $842 \mathrm{~m}$. The evaluated cultivar was BR1. The climate in the region was the "As" equivalent to a hot and humid climate as determined by Köeppen classification (Mota, 1986). Figure 1 shows the meteorological data of precipitation, maximum temperature, minimum and average during the period of the experiment.

\section{The treatments of dairy residue}

The treatments corresponded to the application of dairy residues doses of $0,2.5,5,7.5$ and $10 \mathrm{~m}^{3} \mathrm{ha}^{-1}$ and a treatment containing chemical fertilizers of phosphorus and potassium, and three replications.

The milk residue used in the experiment was collected from the treatment plant of dairy company "Bom Gosto", located in Garanhuns-PE city. The residue had the following composition according to the results of chemical analysis: Iron, Manganese, Selenium, Sodium, Copper, Calcium, Potassium and phosphorus $(0.001,0.01,0.0008,0.0005$, $005,0.02,0.03$ and $0.03 \mathrm{mg} \mathrm{L}^{-1}$, respectively) and $\mathrm{pH}=6.2$. The soil that was used as substrate in the pots submitted to chemical analysis and showed a content of $P=3.00 \mathrm{mg} \mathrm{dm}^{-3}$, $\mathrm{K}^{+}=0.07, \mathrm{Ca}^{2+}=0.85, \mathrm{Mg}^{+}=0.55, \mathrm{Na}=0.03, \mathrm{Al}^{3+}=000$ $\mathrm{cmol}_{\mathrm{c}} \mathrm{dm}^{-3}$ and $\mathrm{pH}=5.8$. In control treatment, only $\mathrm{P}+\mathrm{K}$ chemical fertilizers were applied, containing $P$ and $K$ in doses of $15.50 \mathrm{~kg} \mathrm{ha}^{-1}$ as determined by the fertilization manual for the state of Pernambuco (IPA, 2008). Nitrogen was supplied by inoculating seeds with inoculant (SEMIA 6144) commercial Bradiryzobium (Biomax ${ }^{\circledR}$ Premium Peat -

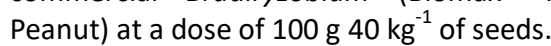

Fifteen days after germination thinning was done leaving only one plant per pot. The cultivar used was peanut BR1, which is recommended for the conditions of semi-arid regions, average cycle of 90 days and produces an average of 1.8 tonnes $\mathrm{ha}^{-1}$ of peanuts in shell (Santos and Suassuna, 2006). The cultural practices were carried out according to the requirements of the crop.

\section{Traits measured}

The following agronomic parameters were evaluated: leaf area which was determined with the apparatus Meter area AM300 and the results presented in $\mathrm{cm}^{2}$; number of rods determined by counting of the stems of plants; plant height - was determined by measuring the main stem of each plant at the end of the crop cycle; the root system length - was obtained by measuring the roots at the end of the cycle; dry weight of shoot and root system-was measured according to Nakagawa (1999) methodology; number of pods - was determined by counting the pods of plants; peanut shell productivity - the productivity obtained was calculated in $\mathrm{kg}$ $\mathrm{ha}^{-1}$; grain productivity - was obtained by weighing of grains and the results converted to $\mathrm{kg} \mathrm{ha}^{-1}$.

\section{Statistical analysis}

The experimental design was a randomized block with three replications and six treatments. Data were subjected to the analysis of variance and means were compared by the Dunnett test at $5 \%$ probability, using SAEG software. The data corresponded to the dairy residue doses were submitted to polynomial regression analysis.

\section{Conclusion}

The dose of $5 \mathrm{~m}^{3} \mathrm{ha}^{-1}$ provided the highest plant height, and the peanut productivity was greater for the dose of $10 \mathrm{~m}^{3}$ ha 1 . The dairy residue can be used as a source of fertilizer on peanut crop by meeting their nutritional needs.

\section{References}

Camilotti F, Silva ARB, Marques MO (2012) Biomass and yield of peanut grown on tropical soil amended with sewage sludge contaminated with lead. Appl Env Soil Scien. 1-6.

Dulewska C, Kudlak S (2002) Mozliwo sciwykorzystania osadów sciekowychw swietle nowych regulacji prawnych. Postepy Nauk Rolniczych, 47-59.

Elayaraja D, Singaravel R (2009) Effect of organic wastes and NPK levels on nutrients uptake and yield of groundnut in coastal sandy soil. Mad. Agri. Jour. Available: Available online

Faostat FAO (2014) Statistics division. Available online.

Gajendragadkar CN, Gogate PR (2016) Intensified recovery of valuable products from whey by use of ultrasound in processing steps - A review. Ultra. Sonoch. 32:102-118.

Godoy IJ, Moraes AS, Siqueira WJ, Pereira JCVNA, Martins ALM, Paulo EM (1999) Yield, stability and adaptability of peanut cultivars in three levels of foliar disease control. Pesq. Agro. Bras. 34 (7):1183-1191.

Hippler FWR, Dias NMS, Hermann ER (2011) Native mycorrhizal fungi and phosphate doses in the 
development of peanut RUNNER IAC 886. Ciênc. Agro. 42 (3): 605-610.

Instituto Agronômico de Pernambuco (2008) Fertilizer recommendations for the state of Pernambuco - 2nd Approach. Recife: Secretária de Agricultura e Reforma Agrária. p. 212.

Lai ZY, Ma XQ, Tang YT, Lin HA (2011) Study on municipal solid waste (MSW) combustion in $\mathrm{N} 2 / \mathrm{O} 2$ and $\mathrm{CO}_{2} / \mathrm{O}_{2}$ atmosphere from the perspective of TGA. Energy. 36 (2): 819-824.

Kvien C (1995) Physiological and environmental disorders of peanuts. In: Melouk HA, Shokes FM. Peanut health management. Minnesota: The American Phytopatological Society. 75-72.

Mantovani JR, Marciza Carrera M, Landgraf PRC, Miranda JM (2015) Acid whey as a source of nutrients for maize. Rer. Bras. Eng. Agri. e Amb. 19 (4): 324-329.

Melo JC, Santos PMS, Santos AC, Alexandrino E, Neto JJP (2014) Morphophysiological response of mombasa grass subjected to doses of dairy liquid residue. Amaz. Jour. of Agri. and Env. Sci. 54(3): 247-258.

Morrill WBB, Rolim MR, Bezerra Neto E, Pedrosa EMR, Oliveira VS, Almeida GLP (2012). Productivity and mineral nutrients in millet and Sudan grass fertilized with whey. Bras. de Eng. Agrí. e Amb. 16 (2): 182-188.

Mota FS, Agendes MOO (1986) Clima e agricultura no Brasil. Porto Alegre: Sagra. 151p. Available online.

Nakagawa J (1999) Testes de vigor baseados no desempenho das plântulas. In: Krzyzanowski FC. Vigor de sementes: conceitos e testes. Londrina: Abrates. 9-13.

Oliveira DQL, Carvalho KTG, Bastos ARR, Oliveira LCA, Marques JJGSM, Nascimento RSMP (2008). Use of leather industry residues as nitrogen sources for elephantgrass. Bras. Cien. Sol. 32: 417-424.
Primo DC, Althoff TD, Dutra ED, Martins JCR, Menezes RSC (2010) Crescimento inicial e teor de nitrogênio em plantas de algodão adubadas com esterco e composto orgânico. In: Anais, Congresso Brasileiro de Mamona e Simpósio Internacional de Oleaginosas Energéticas, 3. João Pessoa, PB.

Queiroz SM (2013) Soro ácido de leite associado a doses de nitrogênio em cobertura na cultura de milho. Jaboticabal: UNESP. Master thesis. 38p.

Saito LM (2007) O uso do lodo de esgoto na agricultura: precauções com os contaminantes orgânicos. Jaguariúna: Embrapa Meio Ambiente. 35p.

Santos PM, Santos AC, Silva JEC, Silva Neto SP, Alexandrino E (2014) Atributos morfogênicos de pastos de capimmombaça adubados com resíduo de laticínio. Caatinga, 27 (3): 221-231.

Santos RC, Moreira JAN, Valle LV, Freire RMM, Almeida RP, Araujo JM, Silva LC (2009) Amendoim BR1. Informações para seu cultivo.

Santos RC, Suassuna TMF (2006) Cultivo do amendoim: Cultivares. Embrapa, Sistema de Produção, no. 7. 2006.

Silva FMG (2010) Fontes e épocas de aplicação de fertilizantes orgânicos no amendoim. Universidade Federal da Paraíba. Master thesis. 56p.

Silva MR, Menezes CSM, Oliveira DFP, Reis TA, Luna UV, Pierangelli MAP (2011) Avaliação da eficiência de resíduos agroindustriais como fonte de nutrientes para pastagens. Pubvet, v. 5, p.111-121.

Vieira IGS (2011) Crescimento vegetativo do amendoim (Arachis hypogaea L.) BR1 em função da aplicação diferenciada de biofertilizantes. Universidade Federal da Paraíba. Graduate Thesis. $48 f$. 